\title{
Acute medial clavicle fracture in adults: a systematic review of demographics, clinical features and treatment outcomes in 220 patients
}

Saeed Asadollahi ${ }^{{ }^{*}}$ and Andrew Bucknill1,2

\begin{abstract}
Background: Medial third clavicle fractures are rare injuries, with limited information available on their characteristics or treatment results.

Materials and methods: We performed a systematic review according to PRISMA guidelines to evaluate the demographics, clinical profile, management and treatment outcome. Electronic searches of the MEDLINE, EMBASE and Cochrane databases were performed.

Results: Seventeen studies were included, consisting of 7 case series and 10 case reports. Two hundred twenty fractures were identified. Seventy-eight percent of fractures occurred in men with mean age of 48 years (16-94 years). Road traffic accident was the most common mechanism of injury (64\%). Associated injuries occurred in $81 \%$ of patients, with thoracic trauma being the most common (47\%). The most common fracture type was extra-articular, with no or minimal displacement (60\%). In $9 \%$ of patients the fracture was segmental. One hundred ninety-one patients received nonoperative treatment. Twenty-nine patients were treated operatively. The overall nonunion rate was $5 \%(7 / 137)$. The nonunion rate following nonoperative management was $4.6 \%(5 / 108)$. The functional result following nonoperative treatment indicated overall "good" functional outcome. There was no report of catastrophic intraoperative complication amongst patients undergoing surgical fixation.

Conclusion: Medial third clavicle fractures represent a distinct subgroup of clavicle fractures. Nonoperative treatment of these fracture seems to result in high union rate and overall favourable functional outcome. Further highquality research in this area is warranted to investigate the outcomes and indication for nonoperative versus operative management of these fractures.
\end{abstract}

Level of evidence: IV.

Keywords: Medial clavicle fracture, Systematic review, Nonunion, Open reduction internal fixation

\footnotetext{
*Correspondence: saeedasadollahi@yahoo.com

1 Department of Orthopaedic Surgery, The Royal Melbourne Hospital,

Parkville, VIC, Australia

Full list of author information is available at the end of the article
} 


\section{Introduction}

Medial clavicle fractures are uncommon injuries, accounting for $2-3 \%$ of all clavicle fractures $[1,2]$. Most medial clavicle fractures have traditionally been treated conservatively $[1,3,4]$. Operative treatment of these fracture is usually considered for open injuries, and fractures with neurovascular compromise or overlying skin compromise $[5,6]$.

With reports indicating unsatisfactory outcome and high nonunion rate following nonoperative treatment of displaced midshaft clavicle fracture [4, 7], an increasing trend is seen towards operative fixation of displaced midshaft clavicle fracture [8]. However, due to the rarity of medial clavicle fractures, the true rate of nonunion and the outcome following nonoperative or operative treatment of these fracture are not well defined [5, 6, 9-11].

The objective of this study is to search the literature, summarise and analyse the demographics, clinical features and treatment outcome of acute medial clavicle fracture in adults.

\section{Materials and methods}

The systematic review was performed following Preferred Reporting Items for Systematic Reviews and MetaAnalyses (PRISMA) guidelines [12].

\section{Search strategy}

In July 2018, an electronic search of MEDLINE (1950 to present) (via PubMed), Embase (via OVID) and Cochrane Database of Systematic reviews (CDSR) was performed. The search terms used were as follows: "clavicle fracture", "medial clavicle fracture", "internal fixation", "bipolar" and "segmental clavicle fracture". Bibliographics of all accessed papers were searched for any undetected studies. English language restriction was applied. The studies were shortlisted if they pertained to medial clavicle fracture epidemiology or management. The abstracts of the shortlisted studies were then reviewed, and selected abstracts were considered for full-text review.

\section{Study inclusion and exclusion criteria}

Studies were included if they reported outcome of treatment of acute medial clavicle fracture in adult (all levels of evidence). We excluded studies with medial clavicle physeal injuries, paediatric and adolescent fractures, nonunion, stress fracture and associated sternoclavicular or acromioclavicular joint dislocation. Two examiners independently assessed the potential eligible studies, and the accuracy and completeness of the primary data.

\section{Quality assessment}

Quality appraisal was performed using the checklist developed by Institute of Health Economics (IHE) [13].
The assessment tool is a 20-criterion quality appraisal checklist. It examines the main domains of a case-series study including study design, population, intervention and co-intervention(s), outcome measures, statistical analysis, results and conclusions, and competing interest and sources of financial support [14].

\section{Data collection and analysis}

Data from included studies were extracted to create the evidence table. Where further clarification was necessary, study authors were contacted directly. Descriptive analysis including measures of frequency, central tendency and dispersion was performed to describe the features of the data using SPSS software (version 25; SPSS, Chicago, IL, USA). Meta-analysis was not performed due to the nature of included studies, being case reports and case series with no control groups.

\section{Results}

The search yielded 17 articles (Fig. 1), comprising 7 clinical studies and 10 case reports (Table 1). A total of 220 adults with medial clavicle fractures were identified. There were 168 men and 48 women $(n=216)$. The mean age at time of trauma was 48 years (range 16-94 years). The most common mechanism of injury was road traffic accident (RTA) (64\%), followed by low fall (17\%), high fall (5\%), direct trauma (5\%), sports (4\%) and other (5\%). The left side was fractured in $54 \%$ of patients. Six fractures were open, and associated vascular injury was reported in one patient. In $9 \%$ of patients the fracture was segmental.

Eighty-one per cent of patients had associated injuries, with thoracic trauma being the most common (47\%). Sixty percent of medial clavicle fractures were undisplaced or minimally displaced extra-articular fractures. Of the seven included observational studies, five were retrospective and two were prospective case series with no controls. The quality assessment results are presented in Table 2.

Twenty-nine (13\%) patients were treated surgically, and $191(87 \%)$ were treated non-surgically. The indication for operative treatment was displacement $(n=21)$, open fracture $(n=5)[5,15]$ and segmental fracture $(n=$ 3) $[10,16,17]$. Most commonly the displacement was anteriorly, but in two patients the medial clavicle fracture was posteriorly displaced $[18,19]$. Various internal fixation implants were used for open reduction and internal fixation (Table 3 ). The implant was removed in $52 \%$ of patients $(n=13)$.

Overall, there were seven non-unions ( $n=137,5 \%)$, and seven complications other than nonunion (six delayed union and one prominent bone). The nonunion rate following nonoperative management was $4.6 \%$ 


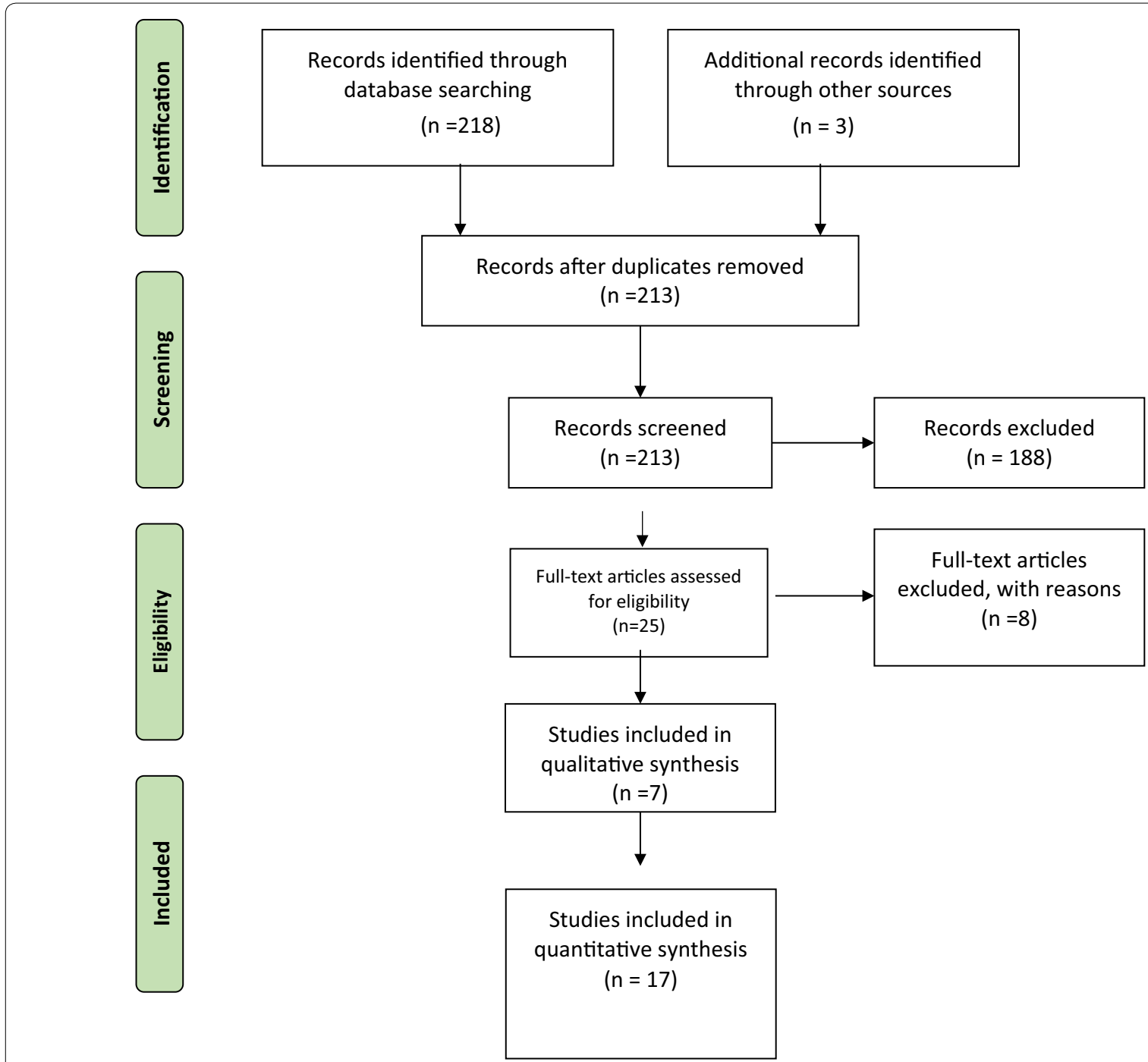

Fig. 1 PRISMA flowchart of literature review and study selection

$(n=108)$. Only five studies evaluated the outcome using an outcome measure tool $(n=50)[9,10,15,17,20]$. Other reports were mainly restricted to general comments on pain and overall range of motion (ROM).

\section{Discussion}

The findings of this systematic review show that medial clavicle fractures represent a distinctive subgroup of clavicle fractures. They commonly occur in middle-aged men as a result of road traffic accident. The high incidence of segmental fractures (9\%) and chest trauma (49\%) implies an association with high-energy trauma. This is in contrast to the overall demographics of clavicle fractures, which commonly occur in men in their early 30 s, with simple fall being the most common mechanism of injury [1].

Nonoperative treatment is known to be the mainstay of management of acute medial clavicle fracture [5, 9]. The review shows an overall high union rate $(95 \%)$ and a "good" functional outcome following nonoperative treatment. The main indications in the literature for operative management of medial clavicle fracture are displacement, open injury and segmental fracture. Nonetheless, absence of controlled studies makes comparison between operative versus nonoperative treatment options difficult. Furthermore, limited radiographic and clinical follow-ups and lack of use of validated outcome assessment tool precludes any further detailed analysis of treatment outcome based on fracture pattern and displacement. 
Table 1 Spreadsheet of included articles

\begin{tabular}{|c|c|c|c|c|c|c|c|c|}
\hline Study (year) & Study design & $\begin{array}{l}\text { No. } \\
\text { of patients }\end{array}$ & Male:female & $\begin{array}{l}\text { Age (years) } \\
\text { Mean } \\
\text { (range) }\end{array}$ & Nonoperative:operative & $\begin{array}{l}\text { Follow-up } \\
\text { duration } \\
\text { (months) }\end{array}$ & Nonunion & $\begin{array}{l}\text { Functional } \\
\text { assessment }\end{array}$ \\
\hline $\begin{array}{l}\text { Bakir et al. [23] } \\
\text { (2017) }\end{array}$ & $\begin{array}{c}\text { Retrospective } \\
\text { case series }\end{array}$ & 17 & $12: 5$ & $57(23-93)$ & $13: 4$ & $-^{\mathrm{a}}$ & 0 & - \\
\hline $\begin{array}{l}\text { Ogawa et al. } \\
\text { [20] (2017) }\end{array}$ & Case report & 1 & $0: 1$ & 74 & $1: 0$ & 36 & 0 & $\begin{array}{l}\text { OSS } 47^{b} \\
\text { ASES } 91.6^{c} \\
\text { Quick DASH } \\
5.0^{d}\end{array}$ \\
\hline $\begin{array}{l}\text { Salipas et al. } \\
\text { [9] (2016) }\end{array}$ & $\begin{array}{l}\text { Retrospective } \\
\text { case series }\end{array}$ & 68 & $53: 15$ & $53.5(16-94)^{e}$ & $68: 0$ & $36(12-72)$ & $2(n=30)$ & $\begin{array}{l}\text { ASES } 80.3 \\
\quad(n=33) \\
\text { SSV } 77 \\
(10-100)^{f} \\
\text { Pain score } 1.9\end{array}$ \\
\hline $\begin{array}{l}\text { Varelas et al. } \\
\text { [17] (2015) }\end{array}$ & Case report & 1 & $0: 1$ & 68 & $0: 1$ & 12 & 0 & DASH: 5 \\
\hline $\begin{array}{l}\text { Wang et al. } \\
\text { [24] (2015) }\end{array}$ & Case report & 1 & $1: 0$ & 40 & $0: 1$ & 12 & 0 & $\begin{array}{l}\text { Full pain-free } \\
\text { ROM }\end{array}$ \\
\hline $\begin{array}{l}\text { Sethi et al. } \\
\text { [25] (2012) }\end{array}$ & Case report & 1 & $0: 1$ & 70 & $1: 0$ & 8 & 0 & - \\
\hline $\begin{array}{l}\text { Oe et al. [15] } \\
\text { (2012) }\end{array}$ & $\begin{array}{l}\text { Retrospective } \\
\text { case series }\end{array}$ & 10 & $9: 1$ & $33.9(16-73)$ & $0: 10$ & $38(14-52)$ & 1 & $\begin{array}{c}\text { DASH } 13.5 \\
(0-66.7)\end{array}$ \\
\hline $\begin{array}{l}\text { Bartonicek } \\
\text { et al. [10] } \\
(2010)\end{array}$ & Case report & 5 & $5: 0$ & $41.6(19-66)$ & $2: 3$ & $17(12-34)$ & 0 & $\begin{array}{c}\text { DASH: } 27 \\
\quad(33.3+27.1) \\
\text { Pain score } 0.6\end{array}$ \\
\hline $\begin{array}{l}\text { Gille et al. [18] } \\
\text { (2010) }\end{array}$ & Case report & 1 & $0: 1$ & 21 & $0: 1$ & 16 & 0 & Pain free $R O M$ \\
\hline $\begin{array}{l}\text { Miller et al. } \\
\text { [26] (2009) }\end{array}$ & Case report & 1 & $1: 0$ & 17 & $0: 1$ & 6 & 0 & Pain-free ROM \\
\hline $\begin{array}{l}\text { McKenna } \\
\text { et al. [19] } \\
\text { (2009) }\end{array}$ & Case report & 1 & $1: 0$ & 23 & $0: 1$ & 2.5 & 0 & Pain-free ROM \\
\hline $\begin{array}{l}\text { Brunner et al. } \\
\text { [22] (2008) }\end{array}$ & Case report & $1^{9}$ & $1: 0$ & 21 & $0: 2$ & 3 & 0 & Pain-free ROM \\
\hline $\begin{array}{l}\text { Throckmorton } \\
\text { et al. [5] } \\
\text { (2007) }\end{array}$ & $\begin{array}{c}\text { Retrospective } \\
\text { case series }\end{array}$ & 55 & $44: 11$ & $46.3(19-88)$ & $51: 4$ & $15.5(n=32)$ & $1(n=10)$ & $\begin{array}{l}72 \% \text { no or mild } \\
\text { pain }\end{array}$ \\
\hline $\begin{array}{l}\text { Haywood and } \\
\text { Clasper [16] } \\
\text { (2005) }\end{array}$ & Case report & 1 & $1: 0$ & 54 & $0: 1$ & 3 & 0 & - \\
\hline $\begin{array}{l}\text { Nowak et al. } \\
\text { [4] (2005) }\end{array}$ & $\begin{array}{l}\text { Prospective } \\
\text { observa- } \\
\text { tional study }\end{array}$ & 4 & - & - & $4: 0$ & 6 & 1 & - \\
\hline $\begin{array}{l}\text { Robinson } \\
\text { et al. [3] } \\
\text { (2004) }\end{array}$ & $\begin{array}{l}\text { Prospective } \\
\text { observa- } \\
\text { tional study }\end{array}$ & 24 & $18: 6$ & $52(29-77)$ & $24: 0$ & 6 & 2 & - \\
\hline $\begin{array}{l}\text { Robinson [1] } \\
\text { (1998) }\end{array}$ & $\begin{array}{l}\text { Retrospective } \\
\text { case series }\end{array}$ & 28 & $22: 6$ & $37.2(13-78)$ & $28: 0$ & - & 0 & - \\
\hline
\end{tabular}

a Not reported

b Oxford shoulder score

c American Shoulder and Elbow Society score

d Disabilities of the arm shoulder and hand

e Median (range)

f Subjective shoulder value

${ }^{9} n=$ bilateral 


\section{Table 2 Completed IHE checklist for case-series studies}

\begin{tabular}{|c|c|c|c|c|c|c|c|}
\hline \multirow[t]{2}{*}{ Criterion } & \multicolumn{7}{|c|}{ Included case series } \\
\hline & Bakir et al. & Salipas et al. & Oe et al. & $\begin{array}{l}\text { Throckmorton } \\
\text { et al. }\end{array}$ & Nowak et al. & $\begin{array}{l}\text { Robinson } \\
\text { et al. }\end{array}$ & Robinson \\
\hline \multicolumn{8}{|l|}{ Study objective } \\
\hline $\begin{array}{l}\text { 1. Was the hypothesis/aim/objective of the study } \\
\text { clearly stated? }\end{array}$ & $Y^{a}$ & Y & Y & Y & Y & Y & Y \\
\hline \multicolumn{8}{|l|}{ Study design } \\
\hline 2. Was the study conducted prospectively? & $N^{b}$ & $\mathrm{~N}$ & $\mathrm{~N}$ & $\mathrm{~N}$ & Y & Y & $\mathrm{N}$ \\
\hline $\begin{array}{l}\text { 3. Were the cases collected in more than one } \\
\text { centre? }\end{array}$ & N & $\mathrm{N}$ & N & N & N & N & Y \\
\hline 4. Were patients recruited consecutively? & $U^{c}$ & $\mathrm{~N}$ & $\mathrm{~N}$ & N & N & Y & Y \\
\hline \multicolumn{8}{|l|}{ Study population } \\
\hline $\begin{array}{l}\text { 5. Were the characteristics of the patients included } \\
\text { in the study described? }\end{array}$ & Y & Y & Y & Y & Y & Y & Y \\
\hline $\begin{array}{l}\text { 6. Were the eligibility criteria (i.e. inclusion and exclu- } \\
\text { sion criteria) for entry into the study clearly stated? }\end{array}$ & Y & Y & Y & Y & Y & Y & Y \\
\hline $\begin{array}{l}\text { 7. Did patients enter the study at a similar point in } \\
\text { the disease? }\end{array}$ & Y & Y & Y & Y & Y & Y & Y \\
\hline \multicolumn{8}{|l|}{ Intervention and co-intervention } \\
\hline 8. Was the intervention of interest clearly described? & Y & Y & Y & Y & Y & Y & Y \\
\hline $\begin{array}{l}\text { 9. Were additional interventions (co-interventions) } \\
\text { clearly described? }\end{array}$ & Y & Y & Y & Y & N & Y & Y \\
\hline \multicolumn{8}{|l|}{ Outcome measures } \\
\hline $\begin{array}{l}\text { 10. Were relevant outcome measures established a } \\
\text { priori? }\end{array}$ & $\mathrm{N}$ & Y & Y & $\mathrm{N}$ & $\mathrm{N}$ & Y & Y \\
\hline $\begin{array}{l}\text { 11. Were outcome assessors blinded to the interven- } \\
\text { tion that patients received? }\end{array}$ & N & $\mathrm{N}$ & $\mathrm{N}$ & $\mathrm{N}$ & $\mathrm{N}$ & N & $\mathrm{N}$ \\
\hline $\begin{array}{l}\text { 12. Were the relevant outcomes measured using } \\
\text { appropriate objective/subjective methods? }\end{array}$ & N & Y & Y & $\mathrm{N}$ & $\mathrm{N}$ & $\mathrm{N}$ & $\mathrm{N}$ \\
\hline $\begin{array}{l}\text { 13. Were the relevant outcome measures made } \\
\text { before and after the intervention? }\end{array}$ & $\mathrm{N}$ & $\mathrm{N}$ & $\mathrm{N}$ & $\mathrm{N}$ & $\mathrm{N}$ & $\mathrm{N}$ & $\mathrm{N}$ \\
\hline \multicolumn{8}{|l|}{ Statistical analysis } \\
\hline $\begin{array}{l}\text { 14. Were the statistical tests used to assess the } \\
\text { relevant outcomes appropriate? }\end{array}$ & Y & Y & Y & N & Y & Y & Y \\
\hline \multicolumn{8}{|l|}{ Results and conclusions } \\
\hline $\begin{array}{l}\text { 15. Was follow-up long enough for important events } \\
\text { and outcomes to occur? }\end{array}$ & N & Y & Y & Y & Y & Y & Y \\
\hline 16. Were losses to follow-up reported? & N & Y & Y & Y & $\mathrm{N}$ & Y & $\mathrm{N}$ \\
\hline $\begin{array}{l}\text { 17. Did the study provide estimates of random vari- } \\
\text { ability in the data analysis of relevant outcomes? }\end{array}$ & N & N & N & N & N & N & N \\
\hline 18. Were the adverse events reported? & N & Y & Y & Y & Y & Y & Y \\
\hline $\begin{array}{l}\text { 19. Were the conclusions of the study supported by } \\
\text { the results? }\end{array}$ & Y & Y & Y & Y & Y & Y & Y \\
\hline \multicolumn{8}{|l|}{ Competing interests and sources of support } \\
\hline $\begin{array}{l}\text { 20. Were both competing interests and sources of } \\
\text { support for the study reported? }\end{array}$ & Y & $\mathrm{N}$ & $\mathrm{N}$ & N & $\mathrm{N}$ & $\mathrm{N}$ & N \\
\hline
\end{tabular}

The process of decision-making on surgical management of medial clavicle fracture can be complicated due to lack of consensus on the indications, and also a potentially challenging nature of surgery. Proximity to vital structures increases the potential risk of catastrophic intraoperative complication [21]. Furthermore, the small size of the medial fragment makes it difficult to achieve adequate fixation. This review shows that, in 
Table 3 Implants and complication profile associated with operative management of medial clavicle fracture

\begin{tabular}{|c|c|c|c|c|}
\hline Study (year) & No. & Implants used & Complication & $\begin{array}{l}\text { Removal } \\
\text { of implant }\end{array}$ \\
\hline Bakir et al. [23] (2017) & 4 & $\begin{array}{l}\text { Recon plate }(n=1)^{\mathrm{a}} \\
\text { Locking plate }(n=1) \\
\text { Locking plate and tightrope }(n=2)^{\mathrm{b}}\end{array}$ & 0 & - \\
\hline Varelas et al. [17] (2015) & 1 & 3.5/2.7-mm locking compression plate & 0 & 0 \\
\hline Wang et al. [24] (2015) & 1 & 3.5/2.7-mm locking compression plate & 0 & 0 \\
\hline Oe et al. [15] (2012) & 10 & $\begin{array}{l}\text { Pilon plate (Synthes Inc.) }(n=2) \\
\text { T oblique locking plate }(3.5 \mathrm{~mm})(n=4) \\
\text { BOS }(3.3 \mathrm{~mm} \text { Stryker Corp, Kalamazoo, MI) }(n=1) \\
\text { LCP compact foot plate }(2.7 \mathrm{~mm} \text {, Synthes Inc.) }(n=1) \\
\text { LCP recon plate }(3.5 \mathrm{~mm})(n=1) \\
\text { DCP }(3.5 \mathrm{~mm})(n=1)\end{array}$ & $\begin{array}{l}\text { Nonunion/hardware } \\
\text { failure }(n=1)\end{array}$ & 8 \\
\hline Bartonicek et al. [10] (2010) & 3 & Cerclage wire $(n=3)$ & 0 & 3 \\
\hline Gille et al. [18] (2010) & 1 & Hook plate & 0 & 1 \\
\hline Miller et al. [26] (2009) & 1 & 4-hole 3.5-mm AO locking reconstruction plate & 0 & 0 \\
\hline McKenna et al. [19] (2009) & 1 & L-shape distal radius plate (2-mm and 2.7-mm screws) & - & 0 \\
\hline Brunner et al. [22] (2008) & 2 & 2.4-mm locking T plate & Broken plate $(n=1)$ & 0 \\
\hline Throckmorton et al. [5] (2007) & 4 & $\begin{array}{l}\text { Open reduction internal fixation (implant not specified) }(n=1) \\
\text { Proximal clavicle resection }(n=2) \\
\text { Irrigation and debridement }(n=1)\end{array}$ & Nonunion $(n=1)$ & 1 \\
\hline Haywood and Clasper [16] (2005) & 1 & - & 0 & 0 \\
\hline
\end{tabular}

the 29 patients in whom the fracture was treated operatively, no intraoperative complication occurred. Staying anterior and superior to clavicle during surgery, and use of unicortical locking screws in the medial fragment, can reduce risk of intraoperative adverse events [21].

Various implants have been used for open reduction internal fixation of medial clavicle fracture. None of the implants revealed by this review have been specifically designed for a medial clavicle fracture. Nevertheless, in many instances, the type of plate selected was aimed at obtaining stable fixation in medial fragment. A lowprofile 2.4-mm plate may not be strong enough to resist torsional and bending forces on clavicle whilst healing occurs. We believe an ideal fixation implant for medial clavicle fracture is yet to be designed [22]. We recommend future cadaveric studies to investigate biomechanical features of such newly developed implant designs.

This systematic review has some limitations. The main body of literature from which the information was extracted has a low quality of evidence. The identified studies were heterogeneous clinically and methodologically. Hence, drawing recommendations regarding the optimal management of medial clavicle fracture was not possible. However, there are circumstances where observational studies are the only form of evidence available and including them in the systematic review might be considered necessary [14]. To the best of the authors' knowledge, this is the only comprehensive review of this very uncommon surgical entity to summarise the literature data on clinical features and treatment of medial clavicle fractures. A multi-centre prospective randomised study with a large number of patients is required to benchmark the outcome of nonoperative versus operative treatment. Such a study would be very difficult (if not impossible) to complete because of the rarity of these injuries.

Medial clavicle fractures most commonly occur in middle-aged men. They most commonly are extraarticular fractures with minimal or no displacement. The current literature shows that nonoperative treatment of these fractures results in high union rate and overall "good" functional outcome (low quality of evidence). There are no reports of any major intraoperative complication in surgical fixation of acute medial clavicle fracture.

\section{Acknowledgements \\ Not applicable.}

Authors' contributions

$S A$ and $A B$ performed preliminary research and drafted the manuscript; $S A$ and $A B$ carried out a final revision before submission. All authors read and approved the final manuscript.

Funding

No funding was received for this study. 
Availability of data and materials

Available on request.

Ethics approval and consent to participate

Not applicable.

\section{Consent for publication}

Not applicable.

\section{Competing interests}

The author declares that they have no competing interests.

\section{Author details}

${ }^{1}$ Department of Orthopaedic Surgery, The Royal Melbourne Hospital, Parkville, VIC, Australia. ${ }^{2}$ Department of Surgery (RMH), Royal Melbourne Hospital, The University of Melbourne, Melbourne, VIC, Australia.

Received: 9 December 2018 Accepted: 10 June 2019

Published online: 28 June 2019

\section{References}

1. Robinson CM (1998) Fractures of the clavicle in the adult. Epidemiology and classification. J Bone Joint Surg Br 80(3):476-484

2. Postacchini F, Gumina S, De Santis P, Albo F (2002) Epidemiology of clavicle fractures. J Shoulder Elbow Surg 11(5):452-456

3. Robinson CM, Court-Brown CM, McQueen MM, Wakefield AE (2004) Estimating the risk of nonunion following nonoperative treatment of a Clavicular fracture. J Bone Joint Surg Am 86(7):1359-1365

4. Nowak J, Holgersson M, Larsson S (2005) Sequelae from clavicular fractures are common: a prospective study of 222 patients. Acta Orthop 76(4):496-502

5. Throckmorton T, Kuhn JE (2007) Fractures of the medial end of the clavicle. J Shoulder Elbow Surg 16(1):49-54

6. Low AK, Duckworth DG, Bokor DJ (2008) Operative outcome of displaced medial-end clavicle fractures in adults. J Shoulder Elbow Surg 17(5):751-754

7. Hill JM, McGuire MH, Crosby LA (1997) Closed treatment of displaced middle-third fractures of the clavicle gives poor results. J Bone Joint Surg $\mathrm{Br}$ 79(4):537-539

8. Canadian Orthopaedic Trauma Society (2007) Nonoperative treatment compared with plate fixation of displaced midshaft clavicular fractures. A multicenter, randomized clinical trial. J Bone Joint Surg Am 89(1):1-10

9. Salipas A, Kimmel LA, Edwards ER, Rakhra S, Moaveni AK (2016) Natural history of medial clavicle fractures. Injury 47(10):2235-2239

10. Bartonicek J, Fric V, Pacovsky V (2010) Displaced fractures of the medial end of the clavicle: report of five cases. J Orthop Trauma 24(4):e31-e35

11. Siebenlist S, Sandmann G, Kirchhoff C, Biberthaler P, Neumaier M (2013) Anatomically precontoured LCP for delayed union of a medial third clavicle fracture. Case report with review of the literature. Acta Chir Orthop Traumatol Cech 80(6):407-410

12. Liberati A, Altman DG, Tetzlaff J, Mulrow C, Gotzsche PC, Ionnidis JP, Clarke M, Devereaux PJ, Kleijnen J, Moher D (2009) The PRISMA statement for reporting systematic reviews and meta-analyses of studies that evaluate health care interventions: explanation and elaboration. Ann Intern Med 151(4):W65-W94

13. Institute of Health Economics (IHE) (2014) Quality APPRAISAL OF CASE SERIES STUDIES CHECKLIST. Edmonton, Institute of Health Economics. http://www.ihe.ca/research-programs/rmd/cssqac/cssqac-about

14. Zeng X, Zhang Y, Kwong JS, Zhang C, Li S, Sun F, Niu Y, Du L (2015) The methodological quality assessment tools for preclinical and clinical studies, systematic review and meta-analysis, and clinical practice guideline: a systematic review. J Evid Based Med 8(1):2-10

15. Oe K, Gaul L, Hierholzer C, Woltmann A, Miwa M, Kurosaka M, Buehren V (2012) Operative management of periarticular medial clavicle fracturesreport of 10 cases. J Trauma Acute Care Surg 72(2):E1-E7

16. Heywood JCR (2005) An unusual case of segmental clavicle fracture. J R Army Med Corps 151:93-94

17. Varelas $N$, Joosse $P$, Zermatten P (2015) Operative treatment of an atypica segmental bipolar fracture of the clavicle. Arch Trauma Res 4(4):e29923

18. Gille J, Schulz A, Wallstabe S, Unger A, Voigt C, Faschingbauer M (2010) Hook plate for medial clavicle fracture. Indian J Orthop 44(2):221-223

19. McKenna M, Widmaier J (2009) Plating of a periarticular medial clavicle fracture. Orthopedics 32(5):366

20. Ogawa T, Sasaki T, Masayuki-Kawashima M, Okawa A, Mahito-Kawashima MK (2017) Internal fixation of only the distal end in a bipolar segmental clavicle fracture: a case report. Malays Orthop J 11:3

21. Sidhu VS, Hermans D, Duckworth DG (2015) The operative outcomes of displaced medial-end clavicle fractures. J Shoulder Elbow Surg 24(11):1728-1734

22. Brunner A, Wedi E, Hoffmann A, Babst R (2008) Bilateral fracture of the medial clavicles treated by open reduction and internal fixation using angle stable locking T-plates. Injury Extra 39:276-278

23. Bakir MS, Merschin D, Unterkofler J, Guembel D, Langenbach A, Ekkernkamp A, Schulz-Drost (2017) Injuries of the medial clavicle: a cohort analysis in a Level-I-Trauma-Center concomitant injuries. Management. Classification. Chirurgia (Bucur) 112(5):594

24. Wang Y, Jiang J, Dou B, Zhang P (2015) Inverted distal clavicle anatomic locking plate for displaced medial clavicle fracture. Arch Orthop Trauma Surg 135(9):1241-1245

25. Sethi K, Newman SD, Bhattacharya R (2012) An unusual case of bipolar segmental clavicle fracture. Orthop Rev (Pavia) 4(3):e26

26. Miller D, Smith KD, McClelland D (2009) Bipolar segmental clavicle fracture. Eur J Orthop Surg Traumatol 19:337-339

\section{Publisher's Note}

Springer Nature remains neutral with regard to jurisdictional claims in published maps and institutional affiliations.

\section{Submit your manuscript to a SpringerOpen ${ }^{\circ}$ journal and benefit from:}

- Convenient online submission

- Rigorous peer review

- Open access: articles freely available online

- High visibility within the field

Retaining the copyright to your article

Submit your next manuscript at springeropen.com 